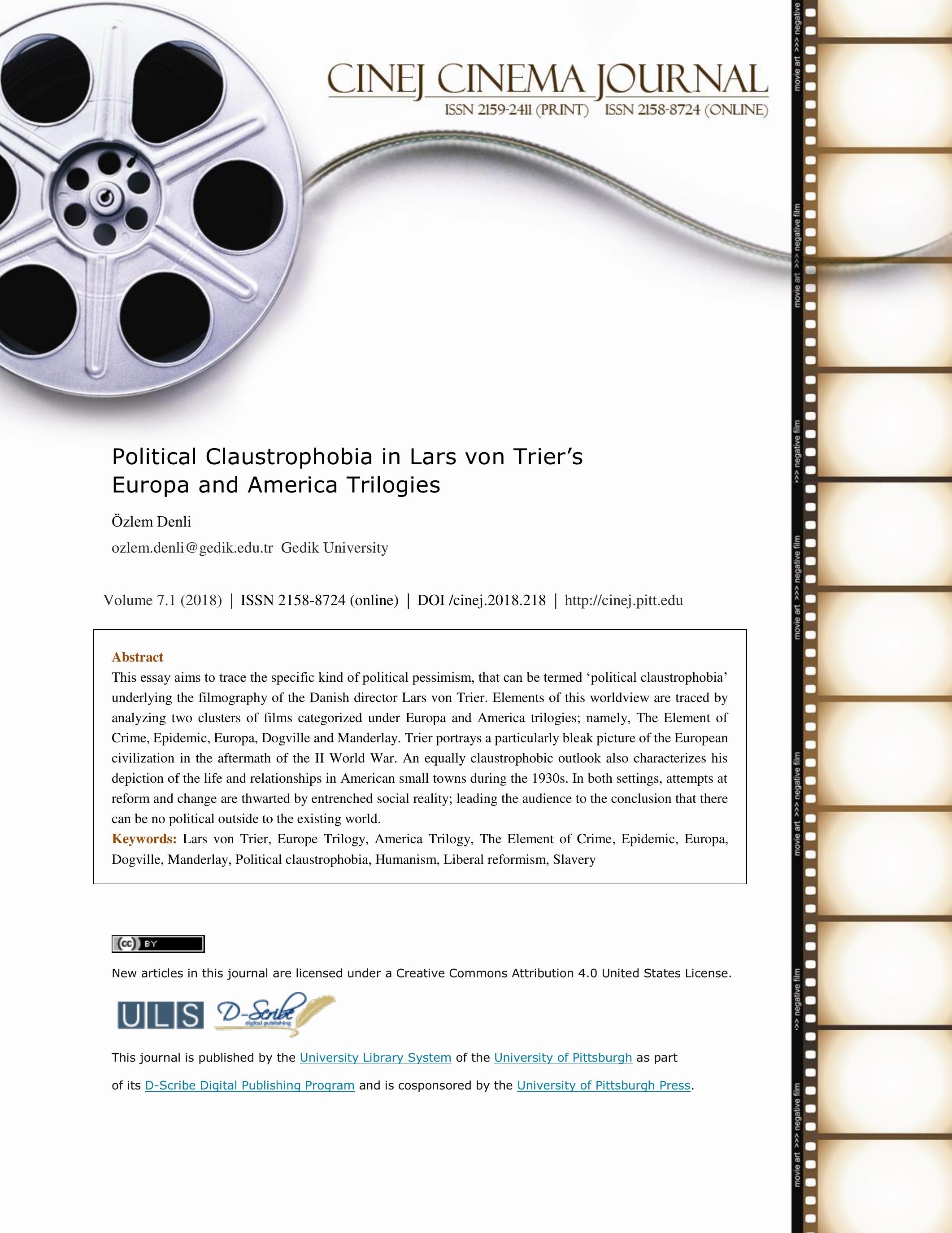




\section{Political Claustrophobia in Lars von Trier's Europa and America Trilogies}

\section{Özlem Denli}

\section{Introduction}

My aim in this essay is to unearth and analyze the political mood and undertones that underlie the cinematography of Danish director Lars von Trier, with particular focus on select films categorized under Europa and American Trilogies. I argue that these clusters of films give expression to an intuit of historical guilt or, alternatively, a human condition which traps the spectator in a feeling of political claustrophobia. ${ }^{1}$

\section{Europa Trilogy}

Europa trilogy is made in the 1980s and the early 1990s. Its first film, The Element of Crime (1984), tells the story of the pursuit of a serial killer (Gary Oldman) by a police officer (Detective Fisher) amidst the background of the post Second World War Europe. The spatial setting of Europe, for Trier, is ultimately and inexorably Germany. As will be seen in other films of the trilogy, The Element of Crime is a tale that journeys into the primordial sin of the European civilization, that is, the unspeakable horrors of Nazism.

Trier takes us through the broken soul of Europe through scenes of hypnosis, ghost-like train stations and elevators descending to underground floors; and the Film Noir inspired aesthetics of the film fits perfectly to this mood. Still, the scenery is also distinctly composite, for Germany

\footnotetext{
${ }^{1}$ The term 'political claustrophobia' is first coined in an article co-authored by the writer. See, Özlem Denli \& Selma Köksal, “Avro-Amerikan Hegemonyası ve Avrupalı Bir Yönetmen Olarak Lars von Trier”.
} 
also functions as the prism that reveals Europe's continuity with the U.S.A., as the 'younger' Europe.

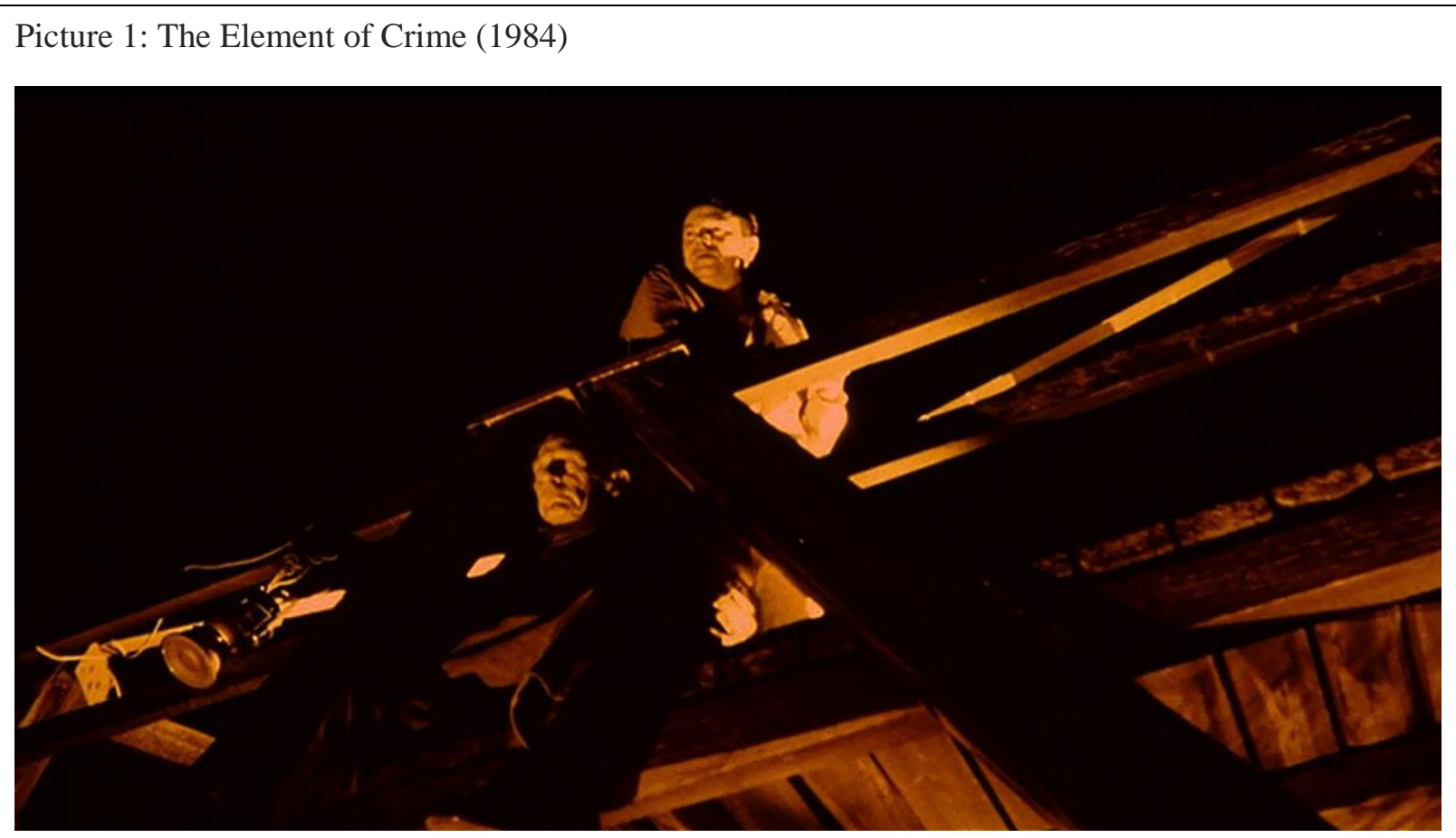

As will be seen in the other two films of the trilogy as well, Trier also constructs the image of a composite timeline that draws upon other periods of history characterized by political aggression and violence. In the Element of Crime, the detective's girlfriend and her son have distinctive Asian features, and in a scene of lovemaking he utters the phrase "I will fuck you to the stone age". This is a direct reference to Coppola's Apocalypse Now, which is a film about the horrors of the Vietnam War (Denli \& Köksal, 2017: 149). Just as the detective and the killer gradually become indistinguishable, monstrosity of recent history blends into the original guilt committed by the Nazi Germany.

The second film of the trilogy, Epidemic (1987), is about a group of script writers working on a grant application, and desperately trying to meet a deadline. Their project is about the history of epidemics in Denmark, and their story is told in juxtaposition with a second level of storytelling that features the actual group of scientists who tried to find a remedy to the outbreak. The 
scriptwriters' story is narrated in a parallel fashion to the spread of the virus. They decide to follow the footsteps of the actual epidemic and make investigations in city archives. The final destination of the journey is set as Germany.

The main character in the script is doctor Memphis, who is portrayed as naïve and idealist even though historical record on him is far more controversial. The writers appear to be detached, even cynical about their topic. In their meetings they discuss an epidemic that hit the vineyards several hundred years ago, while flaunting connoisseur knowledge on vine and vine brands. In the end, they decide to portray doctor Memphis as a cause of the outbreak. The doctor, in his blissful ignorance had travelled across the countryside and spread the virus from the briefcase he carried around. The writers, in this way, imply that working for a solution is something that implicates the person in the very problem they are trying to solve.

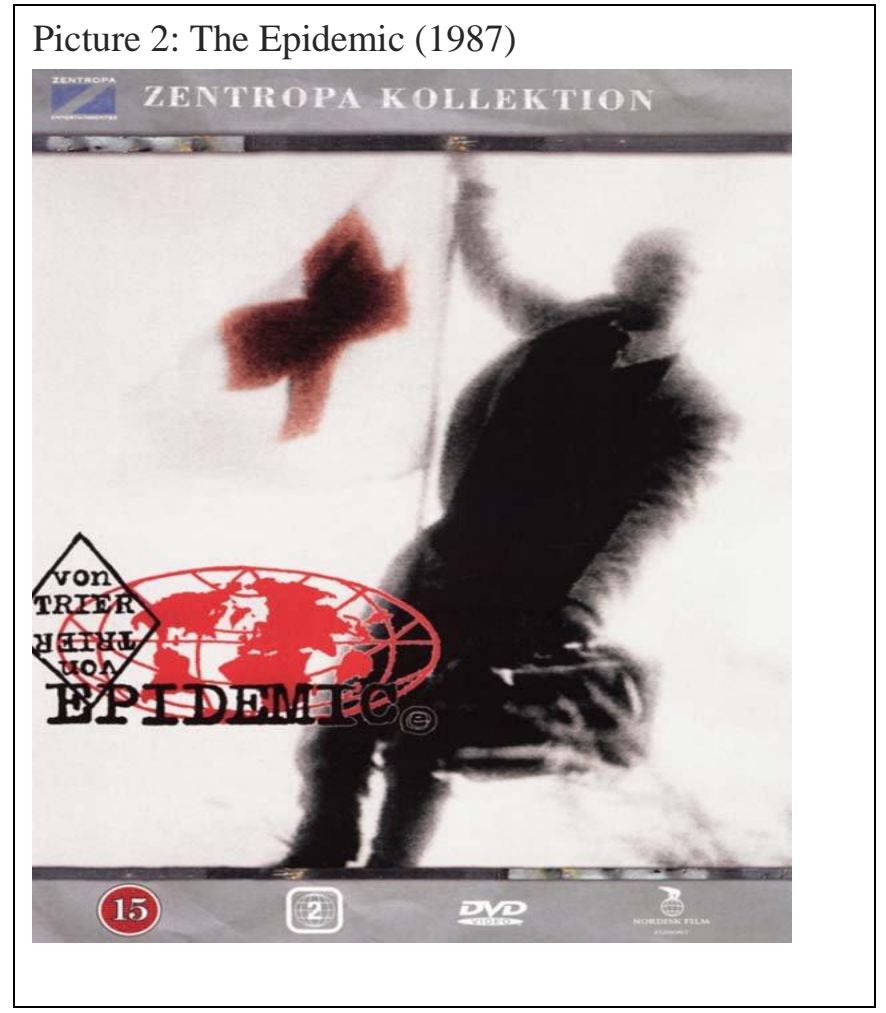


The Epidemic, just like the third film of the trilogy Europa $(1991)^{2}$ seems to be dwelling on the idea of unintended consequences that trap the well-meaning subject, and twist the outcome of their efforts. This idea, in turn, leads us to a uniquely 'Trier-esk' kind of pessimism that can be termed 'political claustrophobia'. Nazi Germany emerges as the epitome of a civilizational decay that swallows any hope of political transversion or subversion. For Trier, there can be no political outside.

It is possible to trace this idea in Europa, which tells the story of Leo Kessler, an American of German origin, who decides to live and work in Germany with a view to help the post-war reconstruction of the country. He takes up employment as conductor in a railway company, only to discover that working there is only open to those who can afford the uniform. In a way, his intentions are warped from the very beginning, since he seems to occupy a position of privilege in a country stricken down by war and poverty.

Already on his first trip, Kessler meets the owner of the company and his daughter Kata and falls in love with her. Their relationship draws Kessler into a web of conspiracies and illicit activity, for his lover - and later wife - turns out to be an ex member of the underground Nazi paramilitary group, the Werewolfs. The group involves Kessler into assassination of a Jewish Major on an overnight assignment, and eventually in a larger sabotage that ends up with the train being bombed while crossing a bridge. Once again, an unknowing hero helps bring about destruction and violence.

Europa makes more explicit use of hypnosis as a narrative device. We hear the outside voice, over low-angle shots speeding along a pair of train tracks at night:

You will now listen to my voice...

\footnotetext{
${ }^{2}$ In the U.S.A., he film was titled Zentropa.
} 
My voice will help you and guide you still deeper into Europa...

I shall now count from one to ten. On the count of ten you will be in Europa...

Seven. You go deeper and deeper and deeper...

On the mental count of ten, you will be in Europa ...

The narrator addresses not only Kessler but also the audience, since we experience the film through his eyes. The hypnotic voice recurs throughout the film, counting to ten as well as summing up wherever we happen to be in the narrative at that moment. In this way, Trier creates a dream-like state and a sense of inevitability and fate (Lund, 2010).

Galt argues that in Europa, "Germany appears to exist at the level of the image, but 'Europa' exists only via the disembodied voice. European space is invisible, existing as a political idea, not as a coherent location" (Galt, 2005: 6). In other words, Germany stands in a "metonymic relation to the troubled political and historical spaces of Europe" (Galt 2005: 5). The hypnotic voice of the narrator reminds the viewer that Germany's original sin is the essence that will give meaning and substance to European civilization both in retrospect and in times to come.

Europa is shot in black-white in the most part, and borrows from German Expressionism, Film Noir and early silent cinema (Lund, 2010). In America trilogy Trier prefers an aesthetics influenced by Brechtian Epic Theater (Atkinson, 2005) ${ }^{3}$, and the plot moves to American small towns in the aftermath of the great depression. Still, the two trilogies are connected via underlying political themes.

\footnotetext{
${ }^{3}$ Dogville is performed on a single sound stage, houses and streets marked only by chalk lines (Atkinson, 2005).
} 


\section{America Trilogy}

America trilogy actually consists of two films: Dogville (2003) and Manderley (2005). In Dogville, we are introduced to the beautiful and elegant Grace, who is running away from some gangsters. She seeks refuge in a poverty-stricken small town. Her initial contact with the town's inhabitants is mediated by Tom Edison, the intellectual and the self-appointed moral leader of the community. Tom persuades the townsfolk so that Grace is 'allowed' to stay there in exchange for helping them with daily chores for a small fee.

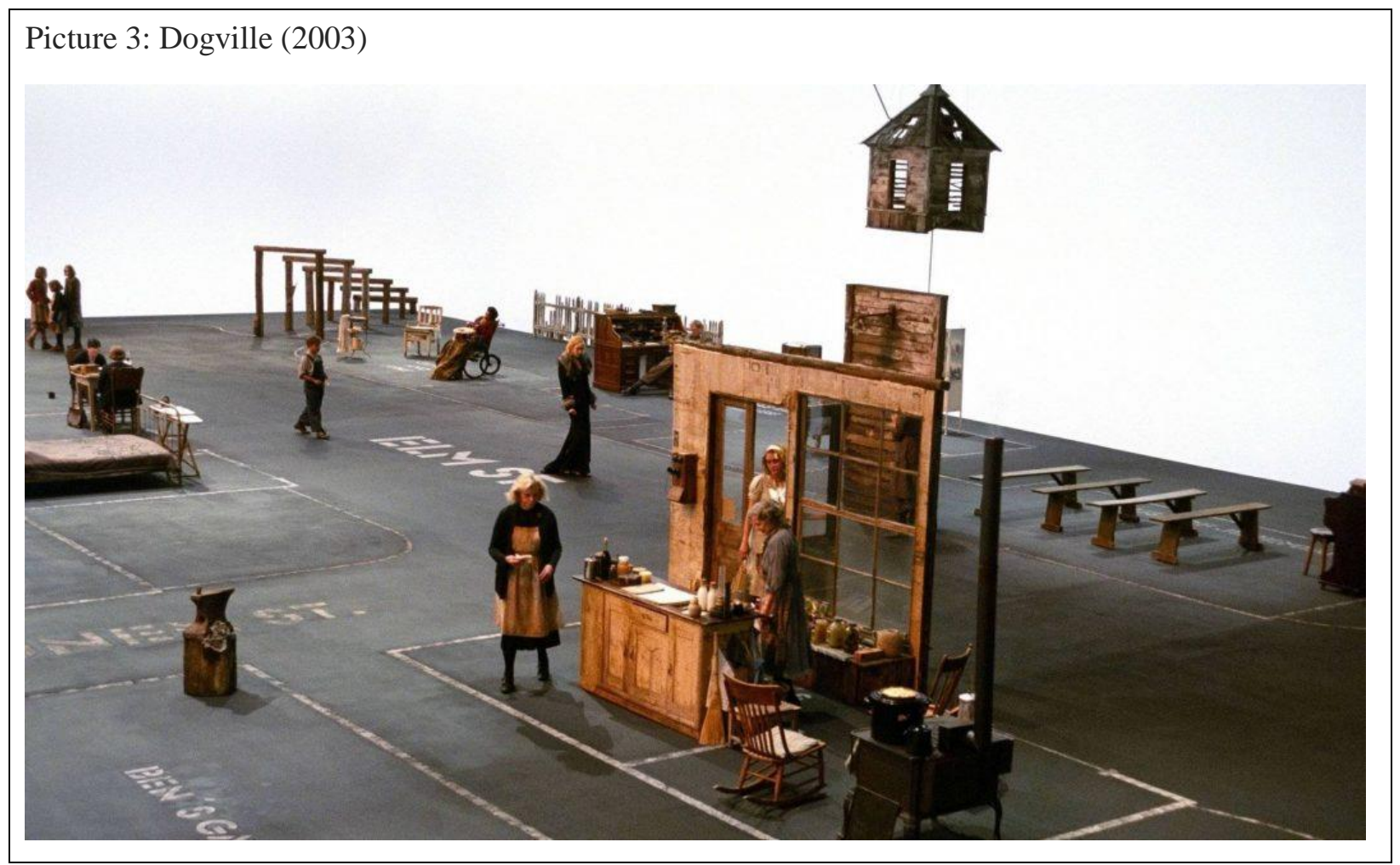

Grace's entire relation with the town changes as the specifics of her situation becomes clear. Visits by the police and the gangsters reveal that she is wanted and is on the run. Her dire need for the safe heaven provided by the town, in turn, changes the agreement with the townsfolk into a much sinister deal.

Grace's vulnerability brings about the worst in Dogville. She is gradually reduced to a slave, and is forced to labor for longer and longer hours without any pay. It is as if the people who 
did not even need her services before, fervently desire and demand her servility in the new situation. Grace's ordeal continues with sexual exploitation and humiliation. She is trapped in a position of victim, and her body is inscribed with all that is perverse and cruel about Dogville. As pronounced by the voiceover, "Dogville bares its teeth", as soon as she is exposed as vulnerable and in need. In the end, her slavery is made explicit by the make-shift shackles she is forced to wear: a heavy fly-wheel fitted with a belled collar.

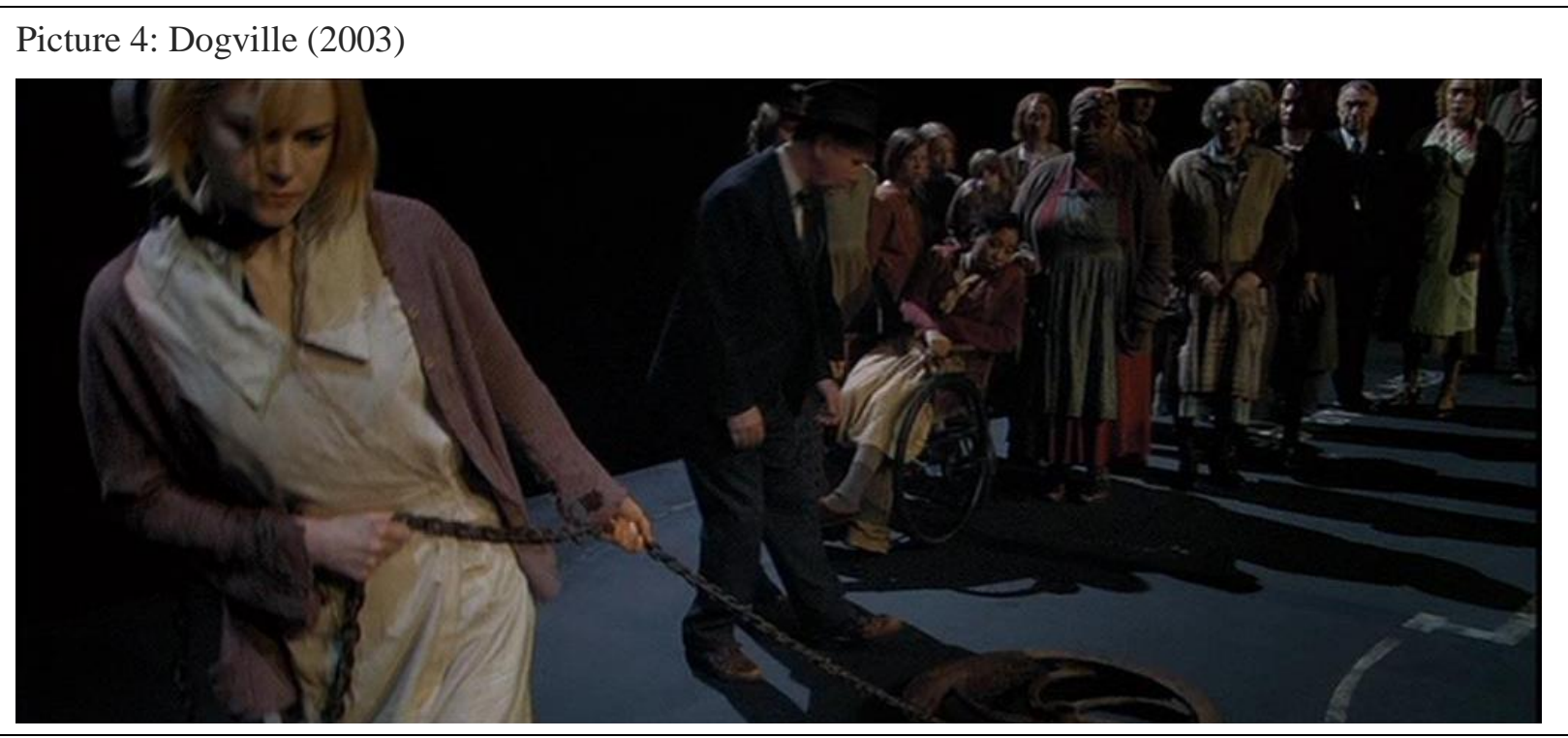

This new status as well is mediated by Tom, who continues to be the intermediary, and justifies everything Grace is subjected to, despite his declared love for her. He is also the one who calls the number left by the gangsters when confronted by the choice between her and his position in the town. In the end it is revealed that the gangsters are actually a crew led by Grace's father, and their rift is about principles of morality. After a long conversation between Grace and her father, she has the entire townsfolk executed, including children and a baby.

On the face of it, Dogville appears to be a tale on human cruelty and baseness that can only be cleansed by an Old Testament kind of justice. This point, indeed, forms the gist of the conversation Grace has with her father in the last part of the film. Still, Trier provides an implicit 
account of a specific logic that is at work in Grace's treatment by Dogville. The film differs from the Europa trilogy in that what is displayed here is not the decadence and decay of the bourgeoisie civilization into fascism. The townsfolk are poor and simple inhabitants, who go about their daily lives and strive to get by under straining economic circumstances. Nonetheless, they are embodiments of a certain kind of rational calculation unrestrained by morality.

This specific logic is already implicit in the initial agreement Tom negotiates on behalf of Grace. At the very first meeting to decide her fate, Tom states that Dogville has forgotten "how to welcome and offer hospitality openly, and what they really need is something for them to accept; a gift". Yet the deal is conditional from the very start. Grace is given two-week trial period to prove herself worthy of trust and useful for the townsfolk. The cold and calculating logic of cost and benefit analysis becomes clearer as the town is visited by the police and the gangsters. As it is pronounced by the omniscient outside narrator, it has become 'costly' to shelter Grace. It seems that Dogville is simply exacting a higher price in return for its risk-taking. The townsfolk, who initially thought there really is not anything they needed doing, adamantly require more time and services of Grace in order to satisfy their newly discovered needs. She is captured, tormented, and before long systematically raped by all men in town who demanded that their sexual needs be satisfied (Atkinson, 2005).

Atkinson compares Dogville to the "fairytale monster who lies in wait, offering hospitality only to consume the guest", ${ }^{4}$ and states that Dogville, in all its monstrosity, plays the host perfectly (Atkinson, 2005). This claim can be augmented by the fact that the horrors of Dogville are specifically based on the logic of market exchange, where the cost of benefit analysis defies interference by moral considerations. Political philosopher John Rawls defines morality as a stance

\footnotetext{
${ }^{4}$ The fable of Hansel and Gretel exemplifies the devouring host perfectly. See Adam Atkinson, "On the Nature of Dogs, the Right of Grace; Forgiveness and Hospitality: Derrida, Kant, and Lars von Trier's Dogville".
} 
that resists changes in the balance of power, and contrasts moral behavior to a simple modus vivendi, which exactly mimics such fluctuations (Rawls, 1993). In this sense "the moral rearmament" proposed by Tom could ever be little more than the calculus of a rational player in the market. Tellingly, Tom's decision to call the gangsters is the ultimate example of the costbenefit analysis, where he makes a rational choice between Grace and his position in the town.

Until the last scenes of Dogville - when Grace massacres the townsfolk - Grace can be listed among the wide-eyed strangers with good intentions, who enter a community only to discover the underlying currents of darkness and deception. What singles out her character is the fact that she is able to exact justice through acquiring means of violence. To cite Machiavelli, Grace has now become an "armed prophet", who can go ahead and bless another American town.

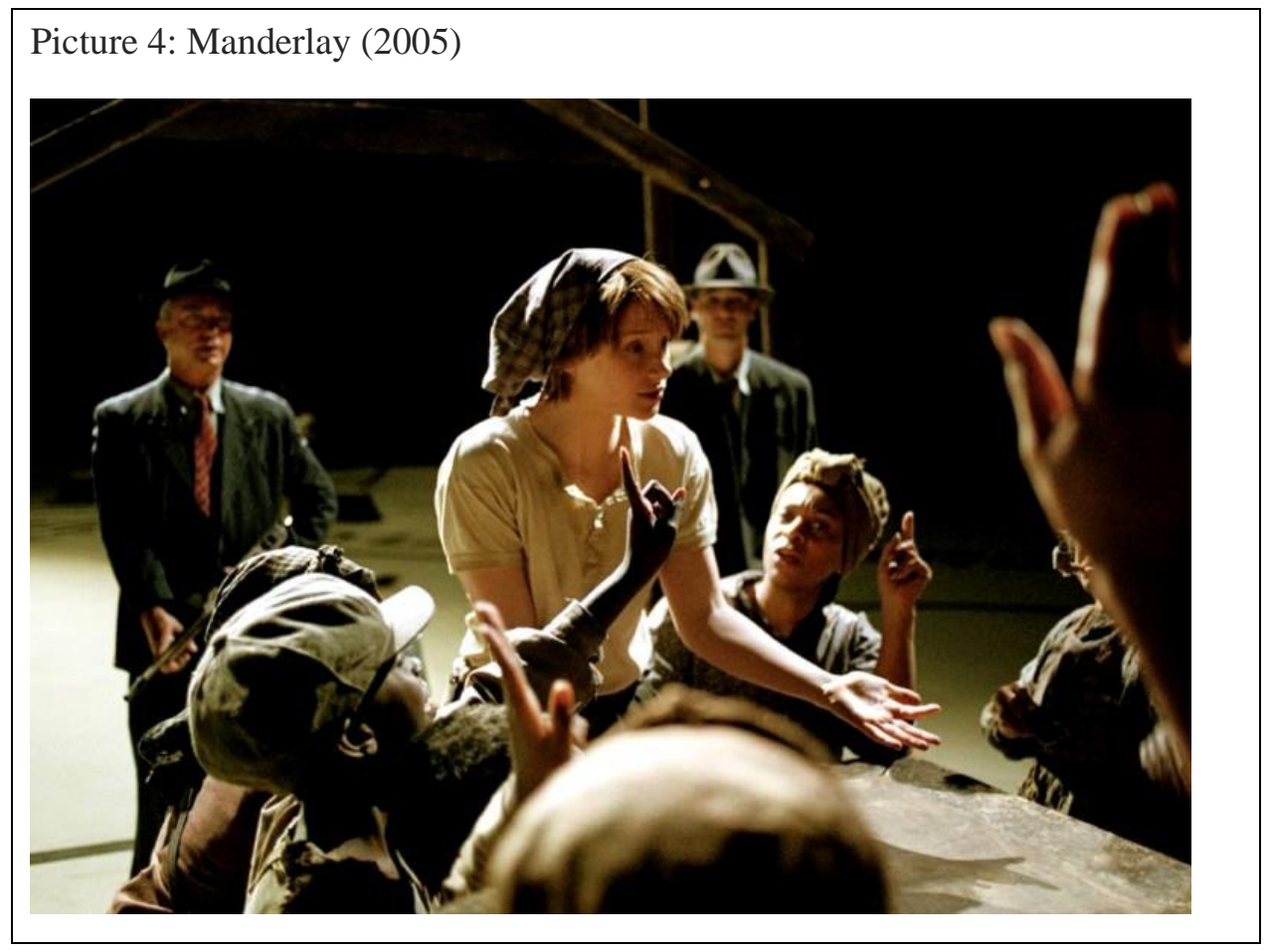

\footnotetext{
${ }^{5}$ Hence it comes about that all armed Prophets have been victorious, and all unarmed Prophets have been destroyed (Machiavelli, 1992).
} 
If Dogville is a theological tale of collapsing love and mercy, Manderlay (2005) is the story of failing liberal reformism. We follow Grace's footsteps into a town that is struggling with slavery so late as 1933. After the matriarch of the town dies, Grace frees the slaves and initiates reforms to facilitate their transition to freedom. Things do not go as Grace had hoped. The newly freed slaves are apathic and lethargic, and the presumed revitalization of human qualities are nowhere to be found. Grace makes them work and hold democratic assemblies at gun point. In the end, the community is betrayed by one of them, who steels and gambles away the entire produce, and the town is swallowed by chaos.

In Manderlay, Grace is a typical humanist and reformist (Lloyd, 2008). After her experience in Dogville, she retains and avails herself to means of violence. Afterall, a true liberal is not an anarchist (Macpherson, 2011). The former slaves of Manderlay, on the other hand, passively resist to their status as free folk. Grace is no longer a desperate asylum seeker but an agent of power; so, she is able to found a modicum of order. She manages to produce and make a profit, but preventing betrayal is beyond her reach. Any hope of a free society is lost together with the stolen harvest money.

It is reasonable to argue that the transition from slavery to freedom is an arduous process. Still, Trier cannot accept even the kind of change that is historically proven to be possible. Trier's former slaves prefer the security provided by the institution of slavery to the risks of freedom and responsibility. We are told that slavery had continued in Manderlay simply because the masters failed to inform the inhabitants about the amendments. Moreover, the former slaves themselves restore the old order by electing Grace as their new mistress. It is also discovered that Mam's Law, a book detailing the rules for running a plantation, was actually written by a slave. Grace's agenda of rational reform is defeated by the townspeople who find slavery more reasonable. 


\section{Conclusion}

Trier tells the stories of outsiders who encounter already existing communities, only to discover that there is no political outside. Their efforts and moral stature are subverted by the established relationships. The outcome is destruction (Europa, Dogville) or a lesser failure (Element of Crime, The Epidemic and Manderlay). His is a world which resists any attempts towards reform and change. Europa trilogy anchors his political claustrophobia in the inexorable undercurrents of horror leading to civilizational decay. In America trilogy, it is the human condition shaped by market rationality and entrenched social structures that thwart the outsiders' well-meaning aspirations for a better world. But what does this fiction mean for us and for the world as we know it? Perhaps we should we immerse ourselves into Trier's fiction, and hail him with the final words of a slave from Manderlay: "Aren't you forgetting something? You made us!"

\section{BIBLIOGRAPHY}

Atkinson, A. (2005). "On the Nature of Dogs, the Right of Grace; Forgiveness and Hospitality: Derrida, Kant, and Lars von Trier's Dogville", Senses of Cinema, 36.

Denli, Ö. \& Köksal, S. (2017). “Avro-Amerikan Hegemonyası ve Avrupalı Bir Yönetmen Olarak Lars von Trier", Folklor/Edebiyat, 23 (89), 147-178.

Galt, R. (2005). "Back Projection: Visualizing Past and Present Europe in 'Zentropa", Cinema Journal, 45(1), 3-21. http://www.jstor.org/stable/3661077

Greenberg, U. E. (2008). The Holocaust Repressed: Memory and the Subconscious in Lars von Trier's Europa, Film \& History: An Independent Journal of Film and Television Studies, 38 (1), 45-52.

Lloyd, V. (2008). Law, Grace, and Race: The Political Theology of Manderlay, Theory \& Event, http://smjegupr.net/wp-content/uploads/2012/08/manderlay.pdf 
Lund, C. (2010). "Europa (Zentropa) A Film by Lars Von Trier (1991)", Film Criticism: Are the Hills Going to March Off?

http://arethehillsgoingtomarchoff.blogspot.com/2010/01/europa-zentropa-film-by-lars-vontrier.html

Machiavelli, N. (1992). The Prince, New York: P.E.Collier \& Son Company

Macpherson, C. B. (2011). The Political Theory of Possessive Individualism: Hobbes to Locke, Oxford: Oxford University Press.

Rawls, J. (1993). Political Liberalism, Harvard: Harvard University Press. 